\title{
Clinical Presentation of Patients with Pituitary Tumour and its Correlation to Magnetic Resonance Imaging: An Observational Study
}

\section{ABSTRACT}

Introduction: Pituitary tumours are common intracranial tumours affecting mainly the $4^{\text {th }}$ to $7^{\text {th }}$ decade of life. A detailed understanding of these pituitary tumour patients, especially regarding their clinical and MRI profile would help in its early detection.It also help in deciding upon further management (medical or surgical or radiation), thus helping in improved outcome.

Aim: To find out the common clinical presentations and the MRI findings of pituitary tumour.

Materials and Methods: A cross-sectional observational study was carried out among 88 patients admitted with diagnosis of pituitary tumour in a tertiary care center from $1^{\text {st }}$ June 2018 to $30^{\text {th }}$ September 2019. The study involved initial clinical assessment followed by MRI brain of all the patients included in the study. To find out relationship between imaging findings and clinical symptoms statistical analysis was done.

Results: The most common clinical presentations were headache in 55 patients (commonly throbbing type in frontal region) and visual field defects in 52 patients (uni/bitemporal hemianopia). A 51 (58\%) patients had suprasellar extension and 35 (39.8\%) patients had tumour already progressed to parasellar extension stage at time of detection of adenoma. Most of the patients detected with pituitary tumours (i.e., 63.6\%) had grade two invasion. Four incidental adenomas were detected and none of them had parasellar extension. Among 35 patients with parasellar extension, $27(77.1 \%)$ patients had visual disturbance. In $45(51.1 \%)$ patients without parasellar extension had no sellar floor involvement. Visual disturbance was significantly associated with the parasellar extension of the tumour.

Conclusion: Headache and visual field defects were the most common clinical presentation among pituitary tumour patients. Patients with tumours having parasellar extension are more likely to have visual disturbance than with patients having only suprasellar extension. Radiologically, pituitary tumours tend to expand only into suprasellar area, then it involves the parasellar area, followed by sellar floor which occurred last.

Keywords: Headache, Parasellar, Suprasellar, Visual field defect

\section{INTRODUCTION}

About $10 \%$ of intracranial tumour are constituted by pituitary tumours. The most common type of pituitary disorder is pituitary adenoma [1]. Based on type of hormone secreted and primary cell of origin, pituitary adenomas are classified into non functioning and functioning adenomas [2]. Pituitary tumours can also be categorised based on their size. If the tumour is more than or equal to $10 \mathrm{~mm}$, it is considered a macroadenoma; if it is smaller than $10 \mathrm{~mm}$, it is considered a microadenoma. Macroadenomas are less common than microadenomas (42.6\% v/s 57.4\%) [3]

Pituitary tumour clinical presentations include signs and symptoms due to mass effect, hypersecretion of pituitary hormones, under secretion of pituitary hormones, features of pituitary apoplexy and incidental detected tumours [Table/Fig-1] [4-30]. These tumours are classified acoording to extension and invasion using Modified Hardy Classification System [31]. The most common age group affected are from forth to seventh decade of life [32].

A clear understanding regarding various clinical presentation of pituitary tumour help in its early detection and treatment. Magnetic Resonance Imaging (MRI) is the imaging investigation preferred for pituitary tumours because of its better soft tissue contrast. MRI also provides important information regarding the gland and the adjacent

\begin{tabular}{|l|l|}
\hline Cause & \multicolumn{1}{c|}{ Clinical presentations } \\
\hline Mass effect & $\begin{array}{l}\text { Headache, visual disturbance (uni/bitemporal hemianopsia, } \\
\text { blurred vision), vomiting, imbalance, urinary incontinence, } \\
\text { memory impairment, } 3^{\text {rd }}, 4^{\text {th }}, 5^{\text {th }} \text { and } 6^{\text {th }} \text { cranial nerve palsy } \\
\text { (ptosis, facial numbness, lateral rectus palsy, double vision), CSF } \\
\text { rhinorrhoea [6-10] }\end{array}$ \\
\hline
\end{tabular}

\begin{tabular}{|c|c|}
\hline \multirow{5}{*}{$\begin{array}{l}\text { Hormone } \\
\text { hypersecretion }\end{array}$} & $\begin{array}{l}\text { Prolactin- Infertility, menstrual disturbance, decreased libido and } \\
\text { galactorrhoea [11,12]. }\end{array}$ \\
\hline & $\begin{array}{l}\text { Adrenocorticotropic Hormone (ACTH) (Cushing's disease)- Weight } \\
\text { gain, ecchymoses, poor wound healing,hyperpigmentation of } \\
\text { skin and mucous membranes, tissue-paper thin skin with easy } \\
\text { bruising, generalised muscle wasting, hypertension, osteoporosis, } \\
\text { emotional lability, depression and dementia [13-17] }\end{array}$ \\
\hline & $\begin{array}{l}\text { Growth Hormone (GH)-Gigantism (GH excess before epiphyseal } \\
\text { closure)- Abnormally tall, very rapid growth, joint pain, increased } \\
\text { sweating }[9,10] \text {. } \\
\text { Acromegaly (GH excess after epiphyseal closure)-Frontal bossing, } \\
\text { prognathism, macroglossia, increasing hand and foot size, thickened } \\
\text { heel pad, glucose intolerance, cardiac arrhythmias and valvular heart } \\
\text { disease, carpal tunnel syndrome, palmar hyperhidrosis, oily skin, } \\
\text { joint pain, fatigue, kidney stones and sleep apnea [9,10,18-20] }\end{array}$ \\
\hline & $\begin{array}{l}\text { Thyroid Stimulating Hormone (TSH)-Heat intolerance, anxiety, } \\
\text { palpitations (due to atrial fibrillation), weight loss despite normal or } \\
\text { increased intake and hyperhidrosis [20-22]. }\end{array}$ \\
\hline & $\begin{array}{l}\text { Gonadotropins \{Luteinising Hormone (LH) and Follicle Stimulating } \\
\text { Hormone (FSH)\}-Usually does not produce a clinical syndrome, } \\
\text { but rarely elevated FSH levels in premenopausal women can } \\
\text { cause amenorrhea or oligomenorrhea and in prepubertal } \\
\text { girls present with vaginal bleeding, breast development, and } \\
\text { abdominal distension }[23,24] \text {. Elevated LH levels in boys rarely } \\
\text { cause precocious puberty [25]. }\end{array}$ \\
\hline $\begin{array}{l}\text { Hormone } \\
\text { under } \\
\text { secretion }\end{array}$ & $\begin{array}{l}\text { Hypopituitarism- Rare, can cause cold intolerance, myxedema, } \\
\text { memory disturbance, unexplained weight loss or weight gain, coarse } \\
\text { hair, dry skin, brittle nails, constipation, increased sleep demand, } \\
\text { orthostatic hypotension, menstrual changes or amenorrhoea in } \\
\text { women, gynecomastia, decreased libido, erectile dysfunction in men, } \\
\text { easy fatigability and hypogonadotropic hypogonadism with anosmia } \\
\text { (Kallmann's syndrome), diabetes insipidus [26-28]. }\end{array}$ \\
\hline $\begin{array}{l}\text { Pituitary } \\
\text { apoplexy }\end{array}$ & $\begin{array}{l}\text { Sudden onset headache, visual disturbance, loss of consciousness } \\
{[29,30] \text {. }}\end{array}$ \\
\hline
\end{tabular}


anatomical structures. This helps in planning medical or surgical or radiation treatment for the patient.

The study was conducted to find out the common clinical presentations and imaging findings in pituitary tumour patients and also to find out the association between extension and invasion of tumour to clinical symptoms. Current literature does not give much information regarding prediction of growth pattern of pituitary tumours using imaging. Knowledge about growth pattern in pituitary tumours is very useful in treatment planning. This study was also aimed to predict the growth pattern in pituitary tumours. The results from the study may help in early detection of pituitary tumour. This may help in early and effective treatment of these tumours.

\section{MATERIALS AND METHODS}

A prospective observational study was carried out in a tertiary care center from $1^{\text {st }}$ June 2018 to $30^{\text {th }}$ September 2019, among patients admitted to Department of Neurosurgery with diagnosis of pituitary tumour. After obtaining Ethical Committee approval (Institutional Review Board Number: 139/2018).

Sample size calculation: Formula for sample size:

Sample Size $(N)=Z \alpha^{2} P Q / d^{2}$

$\{Z \alpha=1.96, P=$ prevalence of various types of pituitary tumour (percentage of nonfunctioning pituitary tumour) $=40.6 \%, Q=(1-P)=59.4 \%, d=a b s o l u t e$ precision $=10 \%\}[33]$

$\mathrm{N}=1.96 \times 1.96 \times 40.6 \times 59.4 / 10 \times 10=92.64 \approx 93$

Inclusion criteria: Diagnosed cases of pituitary tumour by neurosurgeon or neurologist or radiologist were included in this study.

Exclusion criteria: Cases without proper documention of clinical presentation and cases without proper imaging studies were excluded in this study.

\section{Study Procedure}

The study involved assessment of clinical profiles of all pituitary tumour patients admitted in the neurosurgery ward. This included checking of the following symptoms and signs- headache, visual disturbance, vomiting, imbalance, urinary incontinence, memory impairment, $3^{\text {rd }}$, $4^{\text {th }}, 5^{\text {th }}, 6^{\text {th }}$ cranial nerve palsies, infertility, amenorrhoea, decreased libido, galactorrhoea, Cushing's disease, acromegaly, hyperthyroidism, hypopituitarism, features of pituitary apoplexy and asymptomatic (incidentally detected tumours). This was followed by MRI, to classify tumour according to its extension (suprasellar and parasellar extensions) and invasion (size of tumour and involvement of sellar floor) using Modified Hardy Classification system [Table/Fig-2] [31].

\begin{tabular}{|l|l|}
\hline \multicolumn{2}{|l|}{ Extension } \\
\hline Suprasellar & None \\
\hline O & Tumour expanding into suprasellar cistern \\
\hline A & Anterior recesses of 3 ${ }^{\text {rd }}$ ventricle obliterated by tumour \\
\hline B & Floor of $3^{\text {rd }}$ ventricle grossly displaced by tumour \\
\hline C & \multicolumn{2}{|l|}{} \\
\hline Parasellar & Intracranial extension of tumour (intradural) \\
\hline D & Tumour extending into or beneath cavernous sinus (extradural) \\
\hline E & \multicolumn{2}{|l|}{} \\
\hline Invasion/Spread & Sella enlarged; tumour $\geq 10$ mm \\
\hline Floor of sella intact & \multicolumn{2}{|l|}{} \\
\hline I & Localized perforation of sellar floor by tumour \\
\hline II & Diffuse destruction of sellar floor by tumour \\
\hline Sphenoid extension & Distant spread of tumour via CSF or blood-borne \\
\hline III & ITable/Fig-2]: Modified Hardy classification system [31]. \\
\hline IV &
\end{tabular}

\section{STATISTICAL ANALYSIS}

Microsoft Excel software was used to enter the data which was collected. The statistical analysis was done using version 16.0 Statistical Package for the Social Sciences (SPSS) software. Analysis was done to find out the relationship between extension and invasion of tumour to clinical symptoms. Numerical data was represented as mean $\pm S D$, whereas percentages were calculated for categorical data. Cross tabs and Chi-square test were used to compare numerical and categorical variables respectively. Probability $\leq 0.05$ was considered statistically significant.

\section{RESULTS}

The most common age group of presentation was between 41-50 years (28.4\%). The age of presentation ranged from $13-82$ years, with mean age of presentation 51.23 \pm 13.72 years [Table/Fig-3]. Among the 88 patients in study population, 32 (36.4\%) were males and 56 (63.6\%) were females. Among females, 33 (59\%) patients were from the age group of 41-60 years. Male to female ratio was found to be 4:7.

\begin{tabular}{|l|c|c|c|}
\hline Age group (years) & Number of male & Number of female & $\begin{array}{c}\text { Total number } \\
\text { of patients (\%) }\end{array}$ \\
\hline $0-10$ & 0 & 0 & $0(0 \%)$ \\
\hline $11-20$ & 0 & 2 & $2(2.3 \%)$ \\
\hline $21-30$ & 2 & 4 & $6(6.8 \%)$ \\
\hline $31-40$ & 3 & 6 & $9(10.2 \%)$ \\
\hline $41-50$ & 7 & 18 & $25(28.4 \%)$ \\
\hline $51-60$ & 7 & 15 & $22(25 \%)$ \\
\hline $61-70$ & 10 & 9 & $19(21.6 \%)$ \\
\hline $71-80$ & 2 & 2 & $4(4.5 \%)$ \\
\hline $81-90$ & 1 & 0 & $1(1.1 \%)$ \\
\hline [Table/Fig-3]: Age and gender distribution of the study population.
\end{tabular}

The common clinical presentations were headache and visual disturbance seen in 55 (62.5\%) and 52 (59.1\%) patients respectively [Table/Fig-4]. Hormone hypersecretion was seen in 33 (37.5\%) patients, whereas 55 (62.5\%) patients had either normal or low hormone levels.

\begin{tabular}{|l|c|}
\hline Clinical presentation & Number of patients (\%) \\
\hline Headache & $55(62.5 \%)$ \\
\hline Visual disturbance & $52(59.1 \%)$ \\
\hline Vomiting & $26(29.5 \%)$ \\
\hline Imbalance & $12(13.6 \%)$ \\
\hline Memory impairment & $6(6.8 \%)$ \\
\hline Urinary incontinence & $5(5.6 \%)$ \\
\hline Acromegaly & $4(4.5 \%)$ \\
\hline Symptom of apoplexy & $4(4.5 \%)$ \\
\hline Incidental & $4(4.5 \%)$ \\
\hline Cranial nerve palsy & $3(3.4 \%)$ \\
\hline Infertility/Amenorrhoea & $3(3.4 \%)$ \\
\hline Galactorrhoea & $1(1.1 \%)$ \\
\hline Loss of libido & $1(1.1 \%)$ \\
\hline Cushing's disease & $1(1.1 \%)$ \\
\hline Hyperthyroidism & $1(1.1 \%)$ \\
\hline Hypopituitarism & $0(0 \%)$ \\
\hline [Table/Fig-4]: Distribution of clinical presentations (data not mutually exclusive). \\
\hline
\end{tabular}

In the study, only two patients were found without suprasellar extension. A 51 (58\%) patients had suprasellar extension (i.e., stage A, B and C). A 35 (39.8\%) patients had already progressed to parasellar extension stage (i.e., stage D and E) at time of detection of adenoma [Table/Fig-5]. Most of the patients detected with pituitary tumour (i.e., 63.6\%) had grade 2 invasion (sella normal or focally expanded tumour $<10 \mathrm{~mm}$ ) [Table/Fig-5]. 


\begin{tabular}{|l|c|c|c|}
\hline $\begin{array}{l}\text { Extension of } \\
\text { tumour }\end{array}$ & $\begin{array}{c}\text { Number of patients } \\
(\%)\end{array}$ & $\begin{array}{c}\text { Invasion of } \\
\text { tumour }\end{array}$ & $\begin{array}{c}\text { Number of patients } \\
(\%)\end{array}$ \\
\hline Stage 0 & $2(2.3 \%)$ & & $7(8 \%)$ \\
\hline Stage A & $19(21.6 \%)$ & Grade 1 & $56(63.6 \%)$ \\
\hline Stage B & $24(27.2 \%)$ & Grade 2 & $15(17 \%)$ \\
\hline Stage C & $8(9 \%)$ & Grade 3 & $10(11.4 \%)$ \\
\hline Stage D & $19(21.6 \%)$ & Grade 4 & $0(0 \%)$ \\
\hline Stage E & $16(18.1 \%)$ & Grade 5 & [Table/Fig-5]: Distribution of study population based on extension and invasion \\
of tumour.
\end{tabular}

duramater, cranial nerves and blood vessels), meningeal irritation or its involvement in spreading tumours, due to involvement cavernous sinus (contains structures that are sensitive to pain, such as the trigeminal nerve/ganglion and internal carotid artery), increase in intrasellar pressure, psychological and biochemical- neuroendocrine causes [34].

The most common visual disturbance was visual field defects (unilateral/ bilateral temporal hemianopia) in this study. The mass effect caused by the tumour is the main reason for visual field defect [9]. Jane JA et al., and Thapar $\mathrm{K}$ et al., have described pituitary hyperfunction symptoms (such as galactorrhoea, decreased libido, amenorrhoea, infertility, acromegaly) as common clinical presentation [4,5]. But in this study, $62.5 \%$ patients had hormone level either normal or low, which suggest that most of the tumours in the index series were non functioning adenomas and only $37.5 \%$ patients had hormone hypersecretion. Hence, the signs and symptoms due to mass effect were the most common clinical presentations in this study. The study by Bhuyan $\mathrm{M}$ et al., had reported similar results, with most common clinical presentation as headache and visual disturbance seen in $75 \%$ and $50 \%$ patients respectively [33].

In the study, 4 (4.5\%) incidental adenomas were detected, of which one had no suprasellar extension and three had suprasellar extension. But none of them were having parasellar extension, which was found to be statistically significant. This suggests that patient with parasellar extension of pituitary tumour rarely remain asymptomatic. A $10-12 \%$ of patients in the series by Molitch ME were incidentally detected tumours (diagnosed by routine MRI, which showed subtle signal intensity changes in pituitary gland) [35].

In this study, the radiological classification of lesions was done based on Wilson's Modification of Hardy's classification. Regarding extension of tumour, the most common radiological extension was stage B which included 24 patients (27.2\%). This was followed by 19 patients each in stages A and D. A 51 (58\%) patients had suprasellar extension (i.e., stage A, B and C). A 35 (39.8\%) patients had already progressed to parasellar extension stage (i.e., stage $\mathrm{D}$ and E) at time of detection of adenoma. Only two patients were found without suprasellar extension. Ramakrishnan VR et al., in their study on 106 patients, had reported suprasellar extension in 67\% patients [36].

Regarding sellar floor invasion, most of the patients (i.e., 63.6\%) were detected to have grade 2 invasion (sella normal or focally expanded tumour $<10 \mathrm{~mm}$ ). Whereas Grade 1 invasion (sella normal or focally expanded, tumour $10 \mathrm{~mm}$ ) was found only in $8 \%$ patients. A 25 (28.4\%) patients had sellar floor erosion (grade 3 and grade 4). Similar percentages were reported in the study by Scheithauer BW et al., in 1986 among 365 pituitary tumour cases which estimated rate of gross invasion by pituitary adenomas as approximately 35\% [37].

In patients without parasellar extension (51), 26 had no visual disturbance. But among 35 with parasellar extension, 27 (77.1\%) had visual disturbance. Pituitary macroadenoma with suprasellar extension usually develop superior temporal quadrantanopia, but this is often neglected by the patients and when patient presents with visual disturbance, tumour would have extended to parasellar areas and may also have involved other cranial nerves [38]. This might explain the reason for statistically significant relationship between parasellar extension and visual disturbance.

In this study, when sellar floor involvement was compared with parasellar extension, 45 (51.1\%) patients without parasellar extension (i.e., stage 0, and stage A, B, C) did not have sellar floor erosion (i.e., Grade 1 and 2). Where as 19 (21.5\%) patients had both parasellar extension and sellar floor erosion. Again 35 (39.8\%) patients had parasellar extension, whereas 25 (28.4\%) patients only had sellar floor erosion. These findings were found to be statistically significant. This means initially pituitary tumours tend to expand only in suprasellar area without involving the parasellar region or sellar floor. But as it starts to expand further, parasellar extension tend to occur first, and sellar floor involvement occurs last. This may be explained by the 
mechanical property of bone which is hard to erode, hence supra and parasellar extension may occur earlier than sella floor erosion.

\section{Limitation(s)}

The study had more number of patients with non functioning adenomas, due to bias in admission (as most of the functioning adenomas like prolactinomas where managed medically on outpatient basis).

\section{CONCLUSION(S)}

The most common clinical presentations were due to mass effect (as majority of the patients in the study population had non functioning adenomas), which were headache and visual disturbance. Most common type of extension of pituitary tumour detected by imaging was Stage B (Anterior recess of $3^{\text {rd }}$ ventricle obliteration). Most common type of invasion detected in imaging was Grade 2 (sella enlarged, Tumour $\geq 10 \mathrm{~mm}$ ). Patients with tumours having parasellar extension rarely remain asymptomatic. In patients with tumours having parasellar extensions are more likely to have visual disturbance than with patients having only suprasellar extension. Initially, pituitary tumours tend to expand only in suprasellar area without involving the parasellar region or sellar floor. Further expansion results in parasellar extension first followed by sellar floor involvement.

\section{REFERENCES}

[1] Famini P, Maya MM, Melmed S. Pituitary magnetic resonance imaging for sellar and parasellar masses: ten-year experience in 2598 patients. Journal of Clinical Endocrinology \& Metabolism. 2011;96(6):1633-41

[2] Lloyd RV, Kovacs K, Young WF Jr, Farrell WE, Asa SL, Trouillas J, et al. Tumours of the pituitary gland. In: DeLellis RA, Lloyd RV, Heitz PU, et al., eds. World Health Organization Classification of Tumours: Pathology and Genetics of Tumours of Endocrine Organs. Vol. 8. 3rd ed. Lyon, France: IARC Press; 2004: 9-47.

[3] Daly AF, Rixhon M, Adam C, Dempegioti A, Tichomirowa MA, Beckers A. High prevalence of pituitary adenomas: a cross-sectional study in the province of Liege, Belgium. Journal of Clinical Endocrinology \& Metabolism. 2006;91(12):4769-75.

[4] Jane JA Jr, Laws ER Jr. The surgical management of pituitary adenomas in a series of 3,093 patients. J Am Coll Surg. 2001;193(6):651-59.

[5] Thapar K, Kovacs K, Muller PJ. Clinical-pathological correlations of pituitary tumours. Baillieres Clin Endocrinol Metab. 1995;9(2):243-70.

[6] Liu JK, Couldwell W. Pituitary apoplexy: Diagnosis and management. Contemp Neurosurg. 2003;25:01-05

[7] Yen MY, Liu JH, Jaw SJ. Ptosis as the early manifestation of pituitary tumour. $\mathrm{Br}$ J Ophthalmol. 1990;74:188-91.

[8] Telesca M, Santini F, Mazzucco A. Adenoma related pituitary apoplexy disclosed by ptosis after routine cardiac surgery: occasional reappearance of a dismal complication. Intensive Care Med. 2009;35:185-86.

[9] Molitch ME. Diagnosis and treatment of pituitary adenomas: a review. JAMA. 2017;317(5):516-24.

[10] National Cancer Institute. Pituitary Tumours Treatment (PDQ®)-Patient Version. August 18, 2017. Accessed at www.cancer.gov/types/pituitary/patient/pituitarytreatment-pdq on October 16, 2017.

[11] Amar AP, Couldwell WT, Weiss MH. Prolactinomas: focus on indications, outcomes, and management of recurrences. Contemp Neurosurg. 1989;21:01-06.

[12] Klibanski A. Prolactinomas. N Engl J Med. 2010;362:1219-26.
[13] Bertagna X, Raux-Demay M-C, Guilhaume B, Girard F, Luton JP. Cushing's Disease. In: The Pituitary. $2^{\text {nd }}$ ed. Malden, MA: Blackwell Scientific; 2002:496-560.

[14] Cushing $\mathrm{H}$. The basophil adenomas of the pituitary body and their clinical manifestations (pituitary basophilism). Bull John Hopkins Hosp. 1932;50:13795. Google Scholar

[15] Colao A, Petersenn S, Newell-Price J, Findling JW, Gu F, Maldonado M, et al. A 12-month phase 3 study of pasireotide in Cushing's disease. N Engl J Med. 2012;366:914-24.

[16] Feelders RA, de Bruin C, Pereira AM, Romijn JA, Netea-Maier RT, Hermus AR, et al. Pasireotide alone or with cabergoline and ketoconazole in Cushing's disease. N Engl J Med. 2010;362:1846-48.

[17] Tritos NA, Biller BM. Advances in medical therapies for Cushing's syndrome. Discov Med. 2012;13:171-79.

[18] Melmed S. Medical progress: Acromegaly. N Engl J Med. 2006;355:2558-73.

[19] Renehan AG, Shalet SM. Acromegaly and colorectal cancer: risk assessment should be based on population- based studies. J Clin Endocrinol Metab. 2002;87:1909-09.

[20] Lake MG, Krook LS, Cruz SV. Pituitary adenomas: An overview. Am Fam Physician. 2013;88:319-27

[21] Loeffler JS, Shih HA. Radiation therapy in the management of pituitary adenomas. J Clin Endocrinol Metab. 2011;96:1992-2003.

[22] Clarke MJ, Erickson D, Castro MR, Atkinson JLD. Thyroid stimulating hormone pituitary adenomas. J Neurosurg. 2008;109:17-22.

[23] Shimon I, Rubinek T, Bar-Hava I, Nass D, Hadani M, Amsterdam A, et al. Ovarian hyperstimulation without elevated serum estradiol associated with pure folliclestimulating hormone-secreting pituitary adenoma. J Clin Endocrinol Metab. 2001;86:3635.

[24] Gryngarten MG, Braslavsky D, Ballerini MG, Ledesma J, Ropelato MG, Escobar ME. Spontaneous ovarian hyperstimulation syndrome caused by a folliclestimulating hormone-secreting pituitary macroadenoma in an early pubertal girl. Horm Res Paediatr. 2010;73:293.

[25] Ambrosi B, Bassetti M, Ferrario R, Medri G, Giannattasio G, Faglia G. Precocious puberty in a boy with a PRL-, LH- and FSH-secreting pituitary tumour: hormonal and immunocytochemical studies. Acta Endocrinol (Copenh). 1990;122:569.

[26] Ragel BT, Couldwell WT. Pituitary carcinoma: A review of the literature. Neurosurg Focus. 2004;16:E7.

[27] Abe T, Matsumoto K, Sanno N, Osamura Y. Lymphocytic hypophysitis: case report. Neurosurgery. 1995;36:1016-19.

[28] Lieblich JM, Rogol AD, White BJ, Rosen SW. Syndrome of anosmia with hypogonadotropic hypogonadism (Kallmann syndrome): clinical and laboratory studies in 23 cases. Am J Med. 1982;73:506-19.

[29] Bi WL, Dunn IF, Laws ER Jr. Pituitary apoplexy. Endocrine. 2015;48(1):69-75.

[30] Jho DH, Biller BM, Agarwalla PK, Swearingen B. Pituitary apoplexy: large surgical series with grading system. World Neurosurg. 2014;82(5):781-90.

[31] Wilson CB. A decade of pituitary microsurgery. The Herbert Olivecrona lecture. $J$ Neurosurg. 1984;61(5):814-33.

[32] Gittleman H, Ostrom QT, Farah PD, Ondracek A, Chen Y, Wolinsky Y. Descriptive epidemiology of pituitary tumours in the United States, 2004-2009. J Neurosurg. 2014;121:527-35.

[33] Bhuyan M, Sarma D, Dutta D, Yadav Y, Das S. Clinicopathological study of pituitary adenomas in the region of northeast India . Journal of The Arab Society for Medical Research. 2016;11:43-49.

[34] Gondim JA, Almeida JPC, Albuquerque LAF, Schops M, Gomes E, Ferraz T. Headache associated with pituitary tumours. J Headache Pain. 2009;10(1):15-20.

[35] Molitch ME. Incidental pituitary adenomas. Am J Med Sci. 1993;306(4):262-64.

[36] Ramakrishnan VR, Suh JD, Lee JY, O'Malley BW, Grady MS, Palmer JN. Sphenoid sinus anatomy and suprasellar extension of pituitary tumours. Journal of Neurosurgery. 2013;119(3):669-74.

[37] Scheithauer BW, Kovacs KT, Laws ER, Randall RV. Pathology of invasive pituitary tumours with special reference to functional classification. J Neurosurg. 1986;65(6):733-44.

[38] Jung PL, In WP, Yun SC. The volume of tumour mass and visual field defect in patients with pituitary macroadenoma. Korean J Ophthalmol. 2011;25(1):37-41.

\section{PARTICULARS OF CONTRIBUTORS:}

1. Associate Professor, Department of Neurosurgery, Government Medical College, Kottayam, Kerala, India.

2. Senior Resident, Department of Neurosurgery, Government Medical College, Kottayam, Kerala, India.

3. Professor and Head, Department of Neurosurgery, Government Medical College, Kottayam, Kerala, India.

4. Senior Resident, Department of Ophthalmology, Government Medical College, Kottayam, Kerala, India.

\section{NAME, ADDRESS, E-MAIL ID OF THE CORRESPONDING AUTHOR:}

'Kurikkattayil', Muttambalam P.O., Kottayam-686004, Kerala, India

E-mail: geopaul87@gmail.com
Geo Paul K Jose,
PLAGIARISM CHECKING METHODS: [Jain Het al.]

- Plagiarism X-checker: Jan 09, 2021

- Manual Googling: Apr 04, 2021

- iThenticate Software: May 21, 2021 (22\%)
ETYMOLOGY: Author Origin

\section{AUTHOR DECLARATION:}

- Financial or Other Competing Interests: None

- Was Ethics Committee Approval obtained for this study? Yes

- Was informed consent obtained from the subjects involved in the study? Yes

- For any images presented appropriate consent has been obtained from the subjects. NA
Date of Submission: Jan 08, 2021 Date of Peer Review: Apr 05, 2021 Date of Acceptance: May 03, 2021 Date of Publishing: Oct 01, 2021 